\title{
Memory, Place and Pain in W.G. Sebald's The Emigrants
}

\author{
By Kobi (Yaaqov) Assoulin*
}

\begin{abstract}
When we discuss the concept of place, we mostly do so geographically, or as a metaphor. That is, by representing what we think about by geographical notions. This paper avoids this literary tendency by discussing directly the role of actual place in W.G. Sebald's The Emigrants. Not only that, While still acknowledging melancholy's main role in the novel, and the way in which it is discussed in Freud and through Freud et al, the paper takes this melancholy to be a phenomenological spring board for explicating the centrality of place within The Emigrants's melancholy. In order to do this, the paper discusses the role of place within major phenomenological thinkers like Husserl, Heidegger and Merleau-Ponty and the way their discussion dissolves the classical dichotomy of subject/object. However, as this dichotomy is dissolved, it becomes clearer as to the way places do not only belong to human-beings - simultaneously, humans belong to places. Through explicating this, we come to understand in The Emigrants what makes it such a tragic story. While the emigrants find their home to be rooted in places and memories of places, these places carry at the same time a mood of being-athome and alongside that, a sense of ruins which haunt. Thus they become trapped between the conflicting urges of running toward and running from these memories. A dilemma that is finally solved only, in the novel, through death.
\end{abstract}

\section{Introduction}

In The Emigrants, ${ }^{1}$ Sebald presents the story of four emigrants, all of whom are Jews or crypto-Jews, all of them old, born and raised in Europe, and all "forced" to leave Europe due to war, pogroms and antisemitism. Thus, we find the retired Dr. Henry Selwyn, born in the end of the $19^{\text {th }}$ century, now living in a shattered house in England. As he grows older, he becomes increasingly homesick for the place where he was born and lived in until the age of seven. Paul Bereyter is an old teacher who was forced to leave his position and home village due to the Nuremberg Laws, as he is one-quarter of a Jew. We then have Ambrose Adelwarth, who in 1910, at the age of 14, leaves Germany to America to only to begin a life of wandering, leading up to his depression and solitary confinement. Finally, there is Max Ferber, an old painter who as a

*SeniorLecturer, Oranim College of Education, Israel.

1. W.G. Sebald, The Emigrants, trans. Hulse Michael (London: Harvill, 1996). 
child was sent away to England by his parents, who later on perished in the Holocaust. $^{2}$

The Emigrants has been interpreted many times via discussing the melancholy that envelops the main characters. While not disregarding this tendency, I would like to take this psychological situation and provide it with a phenomenological point of view, or rather, to express it within the phenomenological language: to take it from the ontic level to the existentialontological level.

When reading Sebald's books one cannot ignore the way journey is a main motif. Sebald's heroes, as well as the narrator himself, wander constantly from one place to another. However, 'place' and 'journey' are not just metaphors, their function in Sebald's oeuvre, and The Emigrants especially, is to express the firm connection between place, thought and memory. It is a journey from the 'here' and 'now' to the 'there' and then'; from being -"at-home' to being "notat-home". It is a back and forth journey, performed through a constant, even obsessive, act of remembering. In The Emigrants, This pendulum movement of allegedly-forgetting and remembering again forces the protagonists, over and over again, to hide and disclose their world and authenticity all up to a final moment of decision that is comprised of death, mentally at the beginning and finally physically. Thus, there is Dr. Selwyn, who "had been beset in homesickness"3 up to committing suicide with his hunting rifle; And Bereyter, who constantly visits his home-village only to return and "be in the gloomiest of spirit"4 and finally committing suicide. Symbolically, he does this as he lies in front of a train, thereby finally and willingly identifying himself as a Jew. We also have Adelwarth, who suffers up to the point where he commits himself to a sanitarium, that way "longing for extinction as total and irreversible as possible of his capacity to think and remember". ${ }^{5}$ And finally Ferber, who attests to the fact that "beyond a certain point, pain blots the one thing that is essential to its being experienced -consciousness " and thus finds his peace ends when he is hospitalized up to his death.

In order to understand this tragic journey I would like to start by posing the following leading question: what role does place play in their melancholy and memory? However, for doing this let us dwell before on the question of melancholy in the book.

2. In Sebald's original and German written Die Ausgewanderten (1991) Ferber was originally named as Frank Aurach after the real character of Frank Aurach, the English painter. However, later on as Aurach preferred not to be closely identified with the book, Sebald changed it to Ferber.

3. Sebald, The Emigrants, 18.

4. Sebald, The Emigrants, 57.

5. Sebald, The Emigrants, 114. 


\section{Melancholy}

When we discuss memory and recollection we usually think of two modes of memory. The first one is the "trivial", regular mode. In this mode, through recollection, we bring from the past into the present, into consciousness, a meaningful event, and we dwell upon it momentarily. Within that dwelling we picture it, and then we mostly locate ourselves and others in that picture. Such a memory brings about a mental-emotional reaction: a laugh, a tear, sharp sadness, sharp longing, an urge, and so on. These memories can actually fill our field of consciousness vividly, for some time, and we are fully aware of them. Mostly, these moments are relatively brief and they pass away through forgetfulness, through everydayness which takes consciousness away from memories, thus allowing life - within the world - to go on. However, there exists another mode of memory, one that is much less visual and concrete, much more "moody". In this mode, and though the trigger may still be a specific recollection, when that specific recollection disappears visually from consciousness, metaphorically, a certain weight or color remains within consciousness and accompanies our actions, thoughts and personal relations, for a relatively lengthy period of time, maybe even all the time. In The emigrants, the latter possibility rules. Thus, Selwyn "lives in his hermitage, giving his entire attention, ... to thoughts which on the one hand grow vaguer day by day, and, on the other hand, grow more precise and unambiguous". 6 We can see the way those memories and the thoughts that accompany them fill his entire life, thus becoming his hermitage. It should be noted that it is not that they unwillingly haunt him; on the contrary - he is willingly committed to them, he dwells in them, is totally occupied with them. For him there is nothing beyond them, they are ultimate and encapsulate time in its wholeness. ${ }^{7}$ This mode expresses what Heidegger termed a "state of mind" (Stimmungen) ${ }^{8}$. According to this, not only does the human subject (Dasein) always find himself thrown into some facticity, he also projects this mood upon his situations and the beings that surround him:

In having a mood, Dasein is always disclosed mood-wise as that entity to which it has been delivered over in its Being; and in this way it has delivered over to the Being which, in existing, it has to be". 9

6. Sebald, The Emigrants, 11.

7. This constant seclusion is eminent also in "Paul Bereyeter" (p. 58), "Ambros Adelwarth" (p. 103), "Max Ferber" (p. 169).

8. Martin Heidegger, Being and Time, trans. J. Macquarrie and E. Robinson (NewYork: Harper \&Row, 1962, 7ed.), 172-182.

9. Heidegger, Being and Time, 173. 
And though states of mind might change over time, we are always under a certain state-of-mind ${ }^{10}$. What makes this concept of state-of-mind so meaningful is the fact that as a disposition, it makes Dasein comprehend things in the world almost consistently according to this state-of-mind. As Dreyfus describes it:

Mood colors the whole world and everything that comes into it, so that even what I remember, anticipate and imagine is bright or drab, ... In this way moods are like the weather. On a sunny day not only are all present objects bright, but it is difficult to imagine a drab world, and, conversely on dull days everything that can show up is dull, and so is everything one can envisage. ${ }^{11}$

Thus, state-of-mind dissolves the subject-world distinction: the world becomes what the subject makes of it (in terms of intention, apprehending, understanding, caring, approaching, and so on), the subject becomes what the world allows it to be (in terms of identity, consciousness, memories); Dasein becomes a walking state-of-mind. That is why, regarding the protagonists of this book, we can say that 'they live their memories', not as a metaphor, not as a literary cliché, but literally. His protagonists live their memories as an internal, ongoing process - one that fills their daily routines, that navigates and disciplines their daily consciousness; They become enslaved to these memories and to the very act of memory.

What is then the mood that rules the lives of the emigrants? Following Freud it is clear that it is melancholy, as:

The distinguishing mental features of melancholia are a profoundly painful dejection, cessation of interest in the outside world, loss of the capacity to love, inhibition of all activity, and a lowering of the selfregarding feelings to a degree that finds utterance in self-reproaches and self-revilings, and culminates in a delusional expectation of punishment". ${ }^{12}$

Thus, melancholia became a key point for many papers regarding The Emigrants. Carter and Wolff, for example, discuss the way narcissism, part of being melancholic, invites an ethical discussion; ${ }^{13}$ Aliaga-Buchenau, Ceuppens,

10. Heidegger, Being and Time, 174.

11. Hubert Dreyfus, Being-in-the-World (Cambridge, Mass: MIT Press, 1991), 174.

12. Sigmund Freud, "Mourning and Melancholia," in The Standard Edition of the Complete Psychological Works of Sigmund Freud, Volume XIV (1914-1916): On the History of the Psycho-Analytic Movement, Papers on Metapsychology and Other Works (London: Hogarth Press), 237-258, 243.

13. Josephine Carter, "The Ethics of the Melancholic Witness: Janet Frame and W.G. Sebald," in Mosaic: An Interdisciplinary Critical Journal 46, no. 1 (2013): 1-18; Lynn L. Wolff, 
Garloff and Furst do so regarding the way melancholy creates tension between giving public testimony and withdrawing into personal pain (confession). ${ }^{14}$ What this paper intends to do however, is somewhat different. Though I maintain melancholy as a starting point of the discussion, my aim is an ontological-existential analysis, one that takes melancholy, and The Emigrants, to be its ontic-existeniell "object" of analysis ${ }^{15}$.

My main interest and central clue for this is the centrality of place within The Emigrants. This centrality can be observed in two complementing ways. Thus, the emigrants' choice not to be in touch with the real world can be seen from the physical geography of their existence. Selwyn chooses to live within a ruined house (a symbol of his memories and consciousness), "scarcely ever in the house. He lived in his hermitage, giving it his entire attention 16", Bereyter, who closes himself in his room and garden ${ }^{17}$, Adelwarth who leaves his house only to close himself up in a mental sanitarium ${ }^{18}$, and Ferber, who says, "I have rarely been anywhere in my life, except of course Manchester; and even here I often don't leave the house or workshop for weeks on end"19. All of them try not to have any contact with other people, with the world, and generally with what is outside of their body and house. Selwyn has no real connection with his wife and children, Bereyter keeps human contact only with his friend Mme (Lucy) Landau, Adelwarth loses any connection with his widespread family, and at last, Ferber, who imprisons himself in his atelier with his works. We should keep in mind that even the encounters they have with the narrator are when the narrator is the one who penetrates into their physical life, as a fact there is no initiated encounter coming from them. However, on the other hand, it is interesting, when it comes to their memories,

"H.G. Adler and W.G. Sebald: From History and Literature to Literature as Historiography," Monatshefte 103, no. 2, (2011): 257-275.

14. Ana-Isabel Aliaga-Buchenau, "A Time He could not Bear to Say More about: Presence and Absence of the Narrator," in W.G. Sebald: History, Memory, Trauma, ed. S. Denham and M. McCulloh (Berlin: Walter de Gruyter GmbH \& Co, 2006),141-155; Jan Ceuppens, "Transcripts: An Ethics of Representation in The Emigrants," in W.G. Sebald: History, Memory, Trauma, ed. S. Denham and M. McCulloh (Berlin: Walter de Gruyter GmbH \& Co, 2006), 251-264; Katja Garloff, "The Emigrant as Witness: W.G. Sebald's Die Ausgewanderte," in The German Quarterly 77, no. 1(2004), 76-93, 83; Lilian. R. Furst. "Memory's Fragile Power in Kazuo Ishiguro's "Remains of the Day" and W. G. Sebald's "Max Ferber"." In Contemporary Literature 48, no 4(2007), 530-553.

15. My use of ontic-existentiell distinction as to ontological-existential relies of course on Heidegger. For a clear and thorough explanation of this see Dreyfus, Being-in-theWorld, 20-23.

16. Sebald, The Emigrants, 11.

17. Sebald, The Emigrants, 57.

18. Sebald, The Emigrants, 103.

19. Sebald, The Emigrants, 169. 
a clear dissonance comes to the fore - they are immersed in open and dynamic places - this fact is intensified by endless pictures given in the book of those places. Look at the way Sebald describes Adelwarth's trip to the Holy Land. He dedicates an extended paragraph to listing places, around and in Jerusalem: "the Russian cathedral, the Russian Men's and Women's Hospice, the French Hospital de St. Louis, the Jewish Home for the Blind .... "20 - and so on for 31 lines! What is the purpose of presenting such a list? Why does he provide such a list without any details to go along with these places, just names? And after that he suddenly dedicates the last part of the story to a lengthy description of their stay in Ain-Jidy. Look at the way Selwyn describes his journey, with his friend Johannes, to the Alps, or his last memory of leaving his village in a cart. There, he meticulously describes the road and the scenery ${ }^{21}$. Or Ferber's recollection of his trip with his father to Jungfrau Mountain (the Alps again). There is no way of avoiding the centrality and homology between on one hand, melancholy, closed place and being "not-at-home" and on the other hand, open places and being-at-home.22 This centrality goes hand in hand with the places traveled by the narrator himself. However, if for the narrator these places are explicated physically, for the emigrants they are explicated through remembrance. For understanding this one has to understand the role of place and its relation to being-in-the-world, a concept developed phenomenologically and brilliantly through Husserl, Heidegger, Merleau-Ponty and Casey.

\section{Place and the Event of Belonging}

First, it should be admitted that for philosophically explicating the meaning of place, there had to be prior philosophical-historical elimination of its meaning or centrality, and only then a phenomenological resurrection of it. So, as Casey historically-philosophically shows, the scientific-mathematical revolution of the $17^{\text {th }}$ century transformed place, as a subjective concept, to what is "largely discredited, hidden deeply in the folds of the all-comprehensive fabric of space"23. The idea of place lost its intellectual legitimacy up to a point where it was analyzed mathematically and that way objectively, and allegedly accurately. It was understood through the overall concept of space, to be considered not as a place but as a site. ${ }^{24}$ That is, as Descartes' scientific point of

20. Sebald, The Emigrants, 137-140.

21. Sebald, The Emigrants, 19.

22. For the centrality of journey in Sebald's see also John Wylie, "The spectral Geographies of W.G. Sebald," in Cultural Geographies, 14(2007): 171-188.

23. Edward Casey, The Fate of Place: A Philosophical History (Berkeley: University of California Press, 1997), 199.

24. Casey, The Fate of Place, 165. 
view conceived it, containing "nothing but extension in length, breadth, and depth", 25 if there are internal positions and boundaries they become so and described so through geometry, not through any subjective qualities.

However, phenomenologically speaking, as humans we act and think of those "sites" in a human way, normally our intentionality discloses them differently than the physical-mathematical language, or as Husserl puts it most eloquently and ironically: "The disdain with which everything "merely subjective and relative" is treated by those scientists who pursue the modern ideal of objectivity changes nothing of its own manner of being, just as it does not change the fact that the scientist himself must be satisfied with this realm whenever he has recourse, as he unavoidably must have recourse, to it". ${ }^{26}$

And thus phenomenology had to create its own language for what is a place. Yet, it should be said, there is some similarity between place and site, otherwise site could not replace the place of place in our intellectual thinking! We can see this similarity in the way Merleau-Ponty analyzes the relation between the figure [place, site] and the background [world, space], "it [the figure] has an 'outline', which does not 'belong' to the background and which 'stands out' from it", ${ }^{27}$ What makes a figure such is the fact that it has an outline which differentiates it from space which a-priori has no limits. Though these limits allegedly are neutral (they belong to space and to figure at the same time), they actually direct us inside the place, they belong to it. Now, when it comes to site these limits are geometrical, when it comes to place what makes these limits? Now they are perceptual and subjective. When we discuss the notion of site it is clear that the distance is determined geometrically, theoretically and in potential at least, it is infinite. However, when we speak of a place it is assumed to be limited in some subjective ways. Thus, when we live in an apartment we take the walls to be the boundaries of our home, when we live in a private house maybe we will take the yard and its fence to be as such, and maybe as children when we spend much of our daily time in our father's store ${ }^{28}$ we will tend, emotionally at least, to identify it as home. Unlike a site, a place has its human distance, but it is not too much of a distance as it has to keep itself humanly near in some way. Following Heidegger, Casey points out that when we say that things are near we in fact seek "the closeness, the intimacy of things as they are gathered, and themselves actually gather, in a particular place". ${ }^{29}$ But, gathering around what? Let us look at the way the term

25. Quoted in Casey, Edward, Remembering: A Phenomenological Study (Bloomington: Indiana University Press, 2000, 3ed.), 185.

26. Edmond Husserl, The Crisis of European Sciences and Transcendental Phenomenology (Northwestern University Press, 1970), 125.

27. Morice Merleau-Ponty, Phenomenology of perception (London: Routledge, 2002), 15.

28. See the lengthy description of Bereyter's family store, The Emigrants, 51-52.

29. Casey, The Fate of Place, 281. 
'here' works, as Husserl reflects upon this geographical phenomenon. Though 'here' bears, analytically, no defining feature, nor mathematical coordinate, it is totally relativistic, it still functions pragmatically pretty well within a dialog, it is known and relatively precise to our interlocutor, or our consciousness, as it relates to "the privileged position" 30 of the human lived body. Albeit, 'here' holds two opposite properties, it is us a stable point of reference on the one hand (as it refers to the same body), and it is also dynamic as it moves (with the body) within place. Thus, our body becomes a focal point, a necessary condition for the way 'here' functions. When we pay attention to some object within a place, in a way it is always in relation to our body, we put, even imaginatively, our fuzzy location and feeling of 'here' within reach of that object. That way we imaginably gather things around our body, around our 'here', and thus establish a place within place; our body becomes a lived-body as it travels from A to B, it makes B a new focal point for a place, situation and intentionality. ${ }^{31}$ The question that comes is what are the limits of our travelling the 'here' from here to there? As Casey points out to a fragmented text of Husserl, "The World of the Living Present and the Constitution of the Surrounding World External to the Organism" (1931) ${ }^{32}$, it is simply by walking. ${ }^{33}$ This is done as in walking we find three phenomenological ingredients: The (1) 'here', the (2) 'near' and the (3) 'out there'. Thus, though we constantly move on and on in walking, from one point to another, we always stretch our notion of nearness as to our current physical-subjective place ['here', lived-body) and our current intended walking limits as a starting line for what is 'out there'.

Husserl's way of understanding place complies also with the way Heidegger analyzes this, boundaries are defined not by some formal grid or mathematics, but from the inside outward, through the things the subject gathers in his involvement with that environment. Thus, we negotiate with it in terms of closeness, ready-to-hand, ${ }^{34}$ as we humanly measure things in ways like "a good walk", a "stone's throw", or "as long as it takes to smoke a pipe"'.. ${ }^{35}$ Walking, should be said is not just a formal matter of crossing some distance, walking has its own features of involvement. When we walk for a stroll, when we travel, with no intention or hurry to get somewhere, we can activate and involve our attention. This given attention, for a certain thing, creates its place. That way, as we move from one thing to another we create a 'place of all

30. Edmond Husserl, Ding and Raum, 80, quated in Casey, the Fate of Place, 219.

31. Merleau-Ponty, Phenomenology of perception, 112-116.

32. Edmond Husserl, "The World of the Living Present and the Constitution of the Surrounding World External to the Organism," in Husserl: Shorter Works, trans. F. A. Elliston and L. Langsdorf (Notre Dame: University of Notre Dame Press, 1981), 246.

33. Casey, The Fate of Place, 224.

34. Heidegger, Being and Time, 134.

35. Heidegger, Being and Time, 140. 
places', or as Heidegger calls this: a region (Gegend). ${ }^{36}$ That is, every object (thing) has a place of his own and region becomes the matrix which connects them all.

In The Emigrants we can see very clearly the way those emigrants attach their home-memories to such activities consisting of walking and its derivations: Selwyn's trips by foot to the Alps and Crete, and especially the way he describes his departure of his home village:

I can still see the teacher who taught the children in the cheder, where I had been going for two years by then, placing his hand on my parting; I can still see the empty rooms of our house. I see myself sitting topmost on the cart, see the horse's crupper, the vast brown earth, the geese with their outstretched necks in the farmyard mires and waiting room at Grodno station, ......

Thus he continues on and on. We can observe in this, to the way in which the 'here' is changed. At first, the cheder (the religious-traditional Jewish class) is a static I. As he travels with the cart the 'here' changes and along with it places are created on and on within memory. For those who might object to the fact that riding on a cart is not walking, what is important and crucial is of course not the technical action itself, but what it entails phenomenologically. Walking encapsulates a certain rhythm, which at the same time gives us movement while not robbing us of the opportunity to investigate our surrounding, dwell on it, cause us to stop (to rest, to give special attention to something, to allow encountering along the way) and move again. It allows us to get closer, take some distance, touch, smell, look at things from a different angle, and focus. Look what happens when other technologically developed kinesthetic tools (car, train, plane) are adopted, or even - certainly in our capitalist-modern times - when we walk in a rush to our workplace, then the option for attention is very much robbed from us. We start to lose more and more those abilities sketched above, our perceptual capabilities lag behind these tools in terms of rhythm and accessibility. Not only that, if with the body our kinesthetic movement is done through the body, which is "the bearer of the 'I"' as Husserl termed it, ${ }^{37}$ now we meet the world through a technological mediator. We are getting alienated from what is outside that mediator, our immediate surrounding becomes that technological transportation, and the outer surrounding becomes in a way what is 'out there'. In fact, as Malpas claims, technology "replaces the things themselves with images or representations

36. Martin Heidegger, Being and Time, 136.

37. Ding and Raum, 162, quoted in Casey, The Fate of Place, 219. 
(vorstellungen) of things - that is, it re-presents things within a particular "frame" and in a way that is it abstracted from their original locatedness". 38

One of the key existentials in Being and Time is the way Dasein is "born", or thrown, into being-in-the-world. That is, when Dasein is thrown it is into a public arena of mutual understandings, which also helps us "negotiate" or take care of our surrounding (sorge). ${ }^{39}$ What is means is that, paradoxically, "the worlding of the world [das Welten von Welt]" 40 is mainly done through a certain limited place. Dasein's real World is actually its home-surrounding, while world, as that which is total and nothing exists behind it, is what he "infers" only as some abstraction or mood. The way we understand ourselves, and internalize this existential mode as being-in-world, happens not directly through some structured notion of world as a whole universe, and not through unlimited spaces, but through concrete places, mostly very few in number. It becomes clear that though we consciously live with an "abstract" sense of world, what we actually dwell in is a pre-given, human and limited "piece of" of that world. However, this facticity of the world, these pre-ontological understandings, are those which allow Dasein to move hermeneutically in space, or rather in places around him, to disclose an already "partly" given place into a larger place, or as Heidegger terms it, "makingroom (einraumen) $)^{41}$. As, Sheehan analyses it:

the ultimate source of world is the ontological movement of human being that opens the clearing"... Dasein's world-opening movement is what Heidegger calls Ereignis, a term that covers the three moments of a unified process: Dasein's ontological condition of (a) being-opened-up so as to (b) comeinto-its-own and thus (c) finitely appearing - emergence, fulfillment,

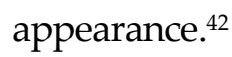

Thus, though its boundaries are fuzzy and subjective they are the ones which bound the place, place becomes more and more "mine", as I become more and more "his". This locality of place is nicely expressed through the fact that Sebald's heroes refer in their home memories mainly not to Germany, Russia or Europe, which are too abstract for being a place; rather, their memories and longings are for certain localized places such as the Selwyn's "cheder", Bereyter's class, Adelwarth's Ain Jidy, Ferber's village (Steinbach) and

38. Jeff Malpas, "Uncovering the Space of Discloedness: Heidegger, technology, and the Problem of Spatiality," in Heidegger, Authenticity, And Modernity (Cambridge, Mass.: MIT Press), 205-228, 226.

39. Dreyfus, $1991,90$.

40. Quoted in Jeff Malpas, Heidegger's Topology: Being, Place, World (Cambridge, Mass.: The MIT Press, 2008), 227.

41. Heidegger, Being and Time, 146.

42. Thomas Sheehan, "Dasein," in A Companion to Heidegger, ed. Hubert Dreyfus and Mark Wrathall (Oxford, Blackwell Publishing Ltd, 2005), 193-213, 202. 
so on. To understand this "evolution" of place dwelling, let us briefly discuss Heidegger's gathering process. We gather a place around us when we find ourselves "having to do with something, producing something, attempting to do something and looking after it, making use of something, giving something up and letting it go, undertaking, accomplishing, evincing, interrogating, considering, discussing, determining..... all these ways of Being-in have concern as their kind of Being". ${ }^{43}$ And so, boundaries point to where we stop taking care of things; it is a mental phenomenon that reflects our practical dealings with the world. As we care for them, these places become, a "container of experiences that contributes to its intrinsic memorability" 44 . That is, the world we meet is in fact a situation, a limited time-place event. This place becomes more and more "designated" when we are able to gather things inside it and when we are "unable" to gather more things and humans outside it. But what is the meaning of this gathering process? What constitutes gathering is linking things together. In this linking we expose these things, that is, we reveal a new meaning and thus they become more than just a presence. Let us observe the way Heidegger discusses this act of gathering with the following geographical example:

The bridge swings over the stream "with ease and power." It does not just connect banks that are already there. The banks emerge as banks only as the bridge crosses the stream.... It brings stream and bank and land into each other's neighborhood. The bridge gathers the earth as landscape around the stream. ${ }^{45}$

The 'banks emerge' not physically of course - but as they acquire their meaning in relation to the bridge; they are released from their mere and silent presence. Their "functionality", and thus meaning, is revealed through the "act" of "bridging".

What makes this gathering and act of belonging is the Event (Ereignis). Heidegger pictures the Event as a certain happening where things are gathered together, as before, but though the event is a down-to-earth one, it is also accompanied by a kind of magic: "[t]he event is not an event among other events", "it is something in which we are 'taken up' and "transformed". ${ }^{46}$ It is an original moment of being-belonged. It discloses our self in relation with a certain place and surrounding; it is the gathering of self and things, which at the same time prevents the self from belonging-gathering in other environments. As a reader you can find this embedded in any of the stories, probably the best illustration of

43. Heidegger, Being and Time, 80; cf. Malpas, Heidegger's Topology, 52-55.

44. Casey, Remembering, 186.

45. Martin Heidegger,"Building, Dwelling, Thinking," in Martin Heidegger: Basic Writings, ed. D. F. Krell (New-York: Harper \& Row, 1977), 330, bold emphasis is mine.

46. Malpas, Heidegger's Topology, 218. 
his are many of the pictures scattered in the books, pictures that catch a moment when suddenly certain scenery is gathered around some human character and thus creates an event of place and not just a site. There are many examples of this but I chose the picture where Bereyter's pupils are gathered together, the only physical object one can discern is a high turret standing behind them, thus converting it from a picture of a bunch of children to that of a place. ${ }^{47}$ But, not just any place, but a human one, as it gathers those children along with that turret. To summarize this, there is no way of separating our sense of selfhood from our sense of our place. There is no sense for the dichotomy subject/object; Dasein should be perceived as an embedded subject-object entity. As that place is said to be mine, but one can also say the opposite, or the complementary, I belong to this place.

\section{Place and Memory}

This puzzle of self and place is still short of one piece: memory. What attaches memory with self and place? There are two reasons for the way place and self are interrelated. First, places are memory-holders, they aid in remembering. ${ }^{48}$ But then - what makes places such suitable candidates for being memory-holders? First, and foremost we remember in pictures, and pictures are mainly places, one can hardly imagine what is not a place - if it is someone's face, a street or a mountain. And despite the fact that out of this detailed concreteness we might perceive a kind of "abstract" feeling - longing, pain, blame, happiness what comes first is a certain picture ${ }^{49}$. The visual detailed richness of places serves as a hanger for our emotional memories. Thus, places are a kind of technical cognitive tool for accessing events and people in our past. That is why we say that we go back again and again to our memories; it is a way of restoring an event, as memories provide the conditions of stability and persistency..$^{50}$ Secondly, and probably more important, when we speak of the memories we find in The Emigrants, we actually refer to what is popularly called "defining moments". But in order to be considered as a defining moment - of the self - that moment has to be itself defined, it has to have the character of a moment. That is, it has to have boundaries of place and time, and be discernible from other moments. And not only that, through recollection, through "walking" in them, we can purify and explicate these memories more and more. All these limitations and characteristics go hand in hand with the way we have discussed place. As we remember, we emulate the phenomenological feature of walking in place as we actually

47. Sebald, The Emigrants, 39.

48. Casey, Remembering, 182-187.

49. Casey, Remembering, 189.

50. Casey, Remembering, 186-187. 
dwell -mentally- in memory. And just like the way in which places shape selfhood as they introduce themselves as 'our places', so do memories.

However, we all have our memories of the past, even of home, so what is different about Sebald's emigrants? What makes them so painful up to traumatic? It must be said that these emigrants simply fail to blend into their new environments, their existence increasingly becoming a living within a ruin. This is allegorically featured in the picture of Selwyn's house, in which Sebald anchors a mental picture of memory through exposing the reader to the labyrinths and locking mechanisms inside the house. ${ }^{51}$ As readers, we can clearly discern that the house, with its two big dark windows, remarkably simulates an owl, that common metaphor for a deep, gloomy, sunken, dark memory, one that is looking back at us (As a reader I found no way to avoid imagining it to be a staring owl, when looking at it). This homology of house, memory and ruin goes on: notice the way Sebald describes Dr. Selwyn's garden, where you can find at least three features for this ruin metaphor: "But now the court has fallen into [1]disrepair, like so much else around here. It's not only the kitchen garden, he continued, indicating the tumble-down Victorian greenhouses and overgrown espaliers, that's on its last legs after years of [2]neglect. More and more, he said, he sensed that Nature itself was groaning and [3]collapsing beneath the burden we placed upon it". ${ }^{52}$ This disrepair, neglect and collapsing describe not only his house but his memories as well. Thus, when Selwyn continually counts blades of grass, these are actually his memories, as alluded to by the narrator: "It's a sort of pastime of mine", 53 leading to Selwyn telling the narrator that he is "merely a dweller in the garden, a kind of ornamental hermit". ${ }^{54}$ That is, it is a time where he loses his selfhood, and becomes what Freud termed: The shadow of an object:

An object choice, an attachment of the libido to a particular person [place], had at one time existed; then, owing to a real slight or disappointment coming from this loved person, the object-relationship was shattered. The result was not the normal one of a withdrawal of the libido from this object and a replacement of it on to new one, but something different, for whose coming about various conditions seem to be necessary. The object cathexis proved to have little power of resistance and was brought to an end. But the free libido was not replaced onto another object; it was withdrawn into the ego. There, however it was not employed in an unspecified way, but served to establish an identification of the ego with the abandoned object. Thus the shadow of an object fell upon the ego, and the latter could henceforth be

51. Sebald, The Emigrants, 11.

52. Sebald, The Emigrants, 7.

53. Sebald, The Emigrants, 5.

54. Sebald, The Emigrants, 5. 
judged by a special agency as though it were an object, the forsaken object. ${ }^{55}$

The Reason for this is not stated explicitly by Sebald. However, we can try interpreting this using Heidegger's thought. As we have already noted, every Dasein is thrown into a place, into some cultural tradition, into a public sphere. Albeit, this Heideggerian metaphor misleads, as it is more reasonable to say that every person just finds himself in some place. And using 'find' is not like 'thrown', find is like waking up to some facticity, there is no past in it, it is from zero point to existence, it is accepted naturally, without any potentiality for remorse, guilt, resentment and the like since there is no burden there. Yet, when using the metaphor of 'thrown' one speaks now of a violent movement from one dwelled place to a new one. For Sebald's protagonist's accepting the expectation of dwelling in their new environment, and forgetting their old one, is like betraying their old one, betraying their original self and their commitments to people and places they cherish in these memories.

However, when people are not able to dwell, they actually expose themselves to the "inescapable - that is, "existential" - feature of the human condition", they are unable to fly away from the basic existential situation of homelessness, ${ }^{56}$ or as Heidegger termed it "not-being-at-homeness [das Nichtzuhause-sein]". They lose their ability to hide their homelessness in the inauthentic "they" of their lives. What brings to life this deep understanding, and anxiety, is death. Paradoxically, and tragically though, that home does not exist, culturally or historically anymore. However, through memory it still exists as a ruin - a signifier of death - and as home at the same time. Thus, the memory of being-at-home is at the same time being-in-death. And so the past presents no relation-other than a casual one-with the present. The past becomes true life while the present through remembrance becomes an ongoing death. Thus, living obsessively within memory becomes being-dead. They carry with them a consciousness of life (since home unavoidably signifies this) and death at the same time, reflecting a type of malfunction in existence. ${ }^{57}$ The present is trying to communicate with the past, for the purpose of establishing a stable interpretation of the self that can serve the future, but is unable to do so. Though memory (as a mechanism) reaches memory (as content), it paradoxically captures it as someone else's memory. As Casey comments "[w]e witness the othering of mind into something other than itself. Remembering is in effect a progressive voyage into the othering of memory as traditionally conceived". ${ }^{8}$ Memories, as ruins, become forces that take control of consciousness, they haunt. As Ricoeur points out, memory is not only an entity, but an "activity

55. Freud, "Mourning and Melancholia", 248-258.

56. Young, Julian. "What is Dwelling? The Homelessness of Modernity," in Heidegger, Authenticity, And Modernity (Cambridge, Mass.: MIT Press), 187-204, 188-190.

57. Heidegger, Being and Time, 95-107.

58. Casey, Remembering, xi. 
and a passion in search of a narrative". ${ }^{9}$ As a memory it carries the function, maybe ethical commitment, for transforming the many memories into one, the incidents of life into a story, a group into an 'I'. ${ }^{60}$ However, sometimes this grouping becomes to be only a formal procedure, a proper name ('Henry', 'Paul', 'Max', 'Ambrose') and no more than that; it becomes an identity that is no more than an archive; even when it refers to an 'I', it is one that is broken and dismantled. This sums up to Freud's final conclusion, the object [home-place] has not actually died as it was never there; it is a lost object of love, ${ }^{61}$ home never really existed! This is the moment when Sebald's protagonists tell themselves: we "experience ourselves as a kind of bare, existential projecting [past memories] without any existential projects to project ourselves into [future]". ${ }^{62}$ This is the "possibility of impossibility", the impossibility of "being-at-home".63

This can be seen, clearly and radically, In "Paul Bereyter". This is perhaps the only place in The Emigrants where the narrator crosses his documentarian role and explicitly expresses his feeling toward Bereyter's community, as silent witnesses and thus as participants, in what was done to him and his family:

[T]he systematic thoroughness with which these people kept silent in the years after the war, kept their secrets, and even, I sometimes think, really did forget, is nothing more than the other side of perfidious way in which Schoferle, who ran a coffee house in S, informs Paul's mother Thekla, who had been on stage for some time in Nuremberg, that the presence of a lady who was married to a half Jew might be embarrassing to his respectable clientele, and begged to request her, with respect of course, not to take her afternoon coffee at his house any more. I do not find it surprising, said Mme Landau, not in the slightest, that you were aware of the meanness and treachery that a family like the Bereyters were exposed to in a miserable hole such as $S$ then was, and such as it still is in despite of all the so-called progress. ${ }^{64}$

And still, as Bereyter finishes his service as a soldier in the German army, he decides to return to his home-village as follows:

[h]e was a German to the marrow, profoundly attached to his native land in the foothills of the Alps, and even to that miserable place called $S$ as well,

59. Paul Ricoeur, "Life in Quest of a Narrative," in On Paul Ricoeur, ed. David Wood (London: Routledge, 1992), 20-33, 29.

60. Ricoeur, "Life in Quest of a Narrative", 21.

61. Freud, Mourning and Melancholia, 245; see also Kaufmann, "Angels Visit the Scene of Disgrace," in Cultural Critique 70(2008): 94-119, 102.

62. Heidegger, Being and Time, 269.

63. Heidegger, Being and Time, 270.

64. The Emigrants, 50. 
which in fact he loathed and, deep within myself, of what I am quite sure, said Mme Landau, would have been pleased to see destroyed and obliterated, together with the townspeople, whom he found utterly repugnant. ${ }^{65}$

We can see here the way Bereyter, irrationally and rationally at the same time, had to recover his sense of home-dwelling and thus returned to his homevillage, which betrayed him. He still goes back to that village. Not because he desires it, but because his memories compell him to it, and because he is unable to free himself of regarding it as his home. However, as Freud recognized, it became a lost object of love, it became an object of hate, though still definitely it is home. This might explain the fact that Sebald's emigrants are not able to create a new sense of home. As they have lost all sense of trust as to the ontic meaning of home, memory becomes a place that haunts. As Wylie, following Derrida, claims:

The self, ..., is in actuality constituted by the attempted exorcism of specters who, as it were in the nature of things, incessantly return to haunt both its 'being' and its 'thereness'. The 'I am' announced in the placing of being-in-theword is, always and necessarily, 'I am haunted'.66

While Freud refers to a person, Sebald shows literarily the way this melancholy can be attached to places, while Husserl, Heidegger et al base this phenomenologically. We can see, through phenomenologically, the way memory/ place functions as some kind of an Other for us. And thus these memories keep defining the present of selfhood - we might call them "existing past memories", as it is expressed, in one of Sebald's cryptic remarks: "For, like death itself, the cemeteries of Constantinople are in the midst of life".67

\section{Conclusion}

If we must put it simplistically, then this paper discusses the way some places are not just places. For Selwyn, Bereyter, Adelwarth and Ferber, it relates to certain defining moments in their life that revealed these places not only as a lost-home, but as a false home, while other moments are able to magically define their home. That is, a place that signifies calmness, belonging, origin, authenticity and selfhood. There are many examples for this in the novel but I believe the best illustration for this is Adelwarth's journey to the Holy Land. As a reader when you read this part of the story you absorb a feeling of desolation, distress, ruin,

65. The Emigrants, 57.

66. Wylie, "The Spectral Geographies of W.G. Sebald," in Cultural Geographies 14 (2007): 171-188, 172.

67. Sebald, The Emigrants, 131. 
filth and sickness, ${ }^{68}$ however suddenly when they arrive at Ain-Jedi, and the Sea of Death (paradoxically), a feeling of home-belonging engulfs Adelwarth, up to a magical event, or Event in Heidegger's language, when:

Suddenly a quail, perhaps frightened by the storm on the sea, took refuge in his lap and remained there, calm now, as if it were its rightful place. ${ }^{69}$

Like that quail, Adelwarth suddenly, and for the only time in the novel, feels he is at home, he is calm. Albeit, this moment is a rare one, mostly in The Emigrants the places we meet, through memory, are places of ruins, they function as a shadow of an object for them. And though we usually regard pain as something that we try to avoid or get rid of, here the picture is much more ambivalent. It is so because memory is not only pain but being-at-home as well. And so pain is at the same time embraced and loathed. All this leads up to the moment when they are faced with their freedom. And so they ask themselves, to put it in Milan Kundera's famous question: "What then shall we choose? Weight or lightness?".70 They choose lightness: death, forgetting.

\section{Acknowledgment}

I would like to thank Oranim Academic College of Education for supporting this study; I would also like to thank Ari Folman for first referring me to Sebald.

\section{Bibliography}

Aliaga-Buchenau, Ana-Isable. "A Time He Could Not Bear to Say More About: Presence and Absence of the Narrator." In W.G. Sebald: History, Memory, Trauma, edited by S. Denham and M. McCulloh. Berlin: Walter de Gruyter $\mathrm{GmbH} \& \mathrm{Co}, 2006$.

Carter, Josephine. "The Ethics of the Melancholic Witness: Janet Frame and W.G. Sebald." In Mosaic: An Interdisciplinary Critical Journal 46, no 1 (2013): 1-18.

Casey, Edward. Remembering: A Phenomenological Study. Bloomington: Indiana University Press, 2000.

Casey, Edward. The Fate of Place: A Philosophical History. Berkeley: University of California Press, 1997.

68. Sebald, The Emigrants, 136-142.

69. Sebald, The Emigrants, 144.

70. Quoted in Casey, Remembering, 4 . 
Ceuppens, Jan. "Transcripts: An Ethics of Representation in The Emigrants." In W.G. Sebald: History, Memory, Trauma, edited by S. Denham and M. McCulloh. Berlin: Walter de Gruyter GmbH \& Co, 2006.

Dreyfus, Hubert. Being-in-the-World. Cambridge, Mass: MIT Press, 1991.

Freud, Sigmund. "Mourning and Melancholia." In The Standard Edition of the Complete Psychological Works of Sigmund Freud, Volume XIV (1914-1916): On the History of the Psycho-Analytic Movement, Papers on Metapsychology and Other Works. London: Hogarth Press.

Furst, Lilian. R. "Memory's Fragile Power in Kazuo Ishiguro's "Remains of the Day" and W. G. Sebald's "Max Ferber"." In Contemporary Literature 48, no 4(2008): 530-553.

Heidegger, Martin. "Building, Dwelling, Thinking." In Martin Heidegger: Basic Writings, edited by DF Krell. New-York: Harper \&Row, 1977.

Heidegger, Martin. Being and Time, translated by Macquarrie John and Robinson Edward. New-York: Harper \&Row, 1962.

Garloff, Katja. "The Emigrant as Witness: W.G. Sebald's Die Ausgewanderte." In The German Quarterly 77, no 1 (2004): 76-93.

Husserl, Edmond. "The World of the Living Present and the Constitution of the Surrounding World External to the Organism." In Husserl: Shorter Works, translated by F. A. Elliston and L. Langsdorf. Notre Dame: University of Notre Dame Press, 1981.

Husserl, Edmond. The Crisis of European Sciences and Transcendental Phenomenology. USA: Northwestern University Press, 1970.

Husserl, Edmond. Ding and Raum. Husserliana 16, The Hague: Nijhof, 1973.

Kaufmann, David. "Angels Visit the Scene of Disgrace." In Cultural Critique 70 (2008): 94-119.

Malpas, Jeff. Heidegger's Topology: Being, Place, World. Cambridge, Mass.: The MIT Press, 2008.

Malpas, Jeff. "Uncovering the Space of Disclosedness: Heidegger, technology, and the Problem of Spatiality." In Heidegger, Authenticity, and Modernity. Cambridge, Mass.: MIT Press, 2000.

Merleau-Ponty, Morice. Phenomenology of perception. London: Routledge, 2002.

Sebald, W.G. Die Ausgewanderten. FISCHER Taschenbuch; Auflage: 16, 1994.

Sebald, W.G. The Emigrants, translated by Hulse Michael. London: Harvill, 1996.

Sheehan, Thomas. "Dasein." In A Companion to Heidegger,edited by Hubert Dreyfus and Mark Wrathall. Oxford, Blackwell Publishing Ltd, 2005.

Wolff, Lynn L. "H.G. Adler and W.G. Sebald: From History and Literature to Literature as Historiography." Monatshefte 103, no 2 (2011): 257-275.

Wylie, John. "The spectral Geographies of W.G. Sebald." In Cultural Geographies 14 (2007): 171-188.

Young, Julian. "What is Dwelling? The Homelessness of Modernity." In Heidegger, Authenticity, and Modernity. Cambridge, Mass.: MIT Press, 2000. 